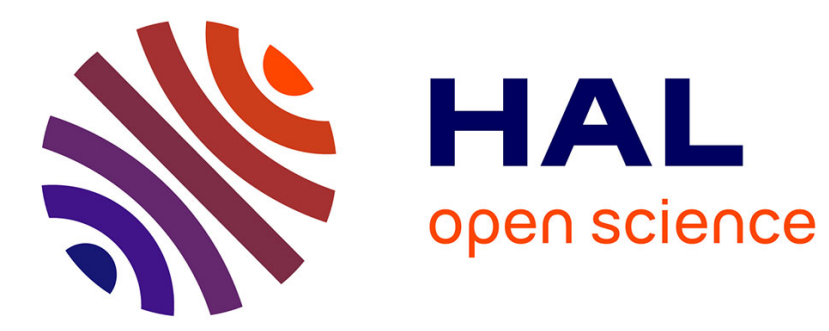

\title{
Partitioning a regional groundwater flow system into shallow local and deep regional flow compartments
}

Pascal Goderniaux, Philippe Davy, Etienne Bresciani, Jean-Raynald de Dreuzy, Tanguy Le Borgne

\section{- To cite this version:}

Pascal Goderniaux, Philippe Davy, Etienne Bresciani, Jean-Raynald de Dreuzy, Tanguy Le Borgne. Partitioning a regional groundwater flow system into shallow local and deep regional flow compartments. Water Resources Research, 2013, 49 (4), pp.2274-2286. 10.1002/wrcr.20186 . insu-00841206

\section{HAL Id: insu-00841206 https://hal-insu.archives-ouvertes.fr/insu-00841206}

Submitted on 4 Jul 2013

HAL is a multi-disciplinary open access archive for the deposit and dissemination of scientific research documents, whether they are published or not. The documents may come from teaching and research institutions in France or abroad, or from public or private research centers.
L'archive ouverte pluridisciplinaire HAL, est destinée au dépôt et à la diffusion de documents scientifiques de niveau recherche, publiés ou non, émanant des établissements d'enseignement et de recherche français ou étrangers, des laboratoires publics ou privés. 


\title{
Partitioning a regional groundwater flow system into shallow local and deep regional flow compartments
}

\author{
Pascal Goderniaux, ${ }^{1,2}$ Philippe Davy, ${ }^{1}$ Etienne Bresciani, ${ }^{1}$ Jean-Raynald de Dreuzy, ${ }^{1}$ and Tanguy Le Borgne ${ }^{1}$ \\ Received 29 November 2012; revised 1 March 2013; accepted 7 March 2013; published 30 April 2013.
}

[1] The distribution of groundwater fluxes in aquifers is strongly influenced by topography, and organized between hillslope and regional scales. The objective of this study is to provide new insights regarding the compartmentalization of aquifers at the regional scale and the partitioning of recharge between shallow/local and deep/regional groundwater transfers. A finite-difference flow model was implemented, and the flow structure was analyzed as a function of recharge (from 20 to $500 \mathrm{~mm} / \mathrm{yr}$ ), at the regional-scale $\left(1400 \mathrm{~km}^{2}\right)$, in three dimensions, and accounting for variable groundwater discharge zones; aspects which are usually not considered simultaneously in previous studies. The model allows visualizing 3-D circulations, as those provided by Tothian models in 2-D, and shows local and regional transfers, with 3-D effects. The probability density function of transit times clearly shows two different parts, interpreted using a two-compartment model, and related to regional groundwater transfers and local groundwater transfers. The role of recharge on the size and nature of the flow regimes, including groundwater pathways, transit time distributions, and volumes associated to the two compartments, have been investigated. Results show that topography control on the water table and groundwater compartmentalization varies with the recharge rate applied. When recharge decreases, the absolute value of flow associated to the regional compartment decreases, whereas its relative value increases. The volume associated to the regional compartment is calculated from the exponential part of the two-compartment model, and is nearly insensitive to the total recharge fluctuations.

Citation: Goderniaux, P., P. Davy, E. Bresciani, J.-R. de Dreuzy, and T. Le Borgne (2013), Partitioning a regional groundwater flow system into shallow local and deep regional flow compartments, Water Resour. Res., 49, 2274-2286, doi:10.1002/wrcr.20186.

\section{Introduction}

[2] The distribution of groundwater fluxes within large deep hydrogeological basin is strongly influenced both by geology and topography. Rivers that are local minima of topographic relief are, with a few exceptions, seepage boundaries for shallow aquifers. The basic organization of topography between hillslope and river network [Montgomery and Dietrich, 1989, 1992] is likely enhancing groundwater fluxes at the hillslope scale with short transfer times. Part of groundwater fluxes is characterized by such short and shallow pathways. The remaining part is characterized by larger transit times, deeper pathways, and groundwater fluxes that can bypass adjacent rivers. The definition of the shallow and deep aquifers as a function of structural and climatic variables, as well as the partitioning between them,

\footnotetext{
${ }^{1}$ Geosciences Rennes, UMR 6118, Université de Rennes 1, Rennes, France.

${ }^{2}$ Geology and Applied Geology, University of Mons, Mons, Belgium.

Corresponding author: P. Goderniaux, Geology and Applied Geology, University of Mons, Mons B-7000, Belgium. (Pascal.Goderniaux@) umons.ac.be)

(C)2013. American Geophysical Union. All Rights Reserved. 0043-1397/13/10.1002/wrcr.20186
}

is not yet clear. This is however critical for understanding the water cycle in large areas and to define a sustainable management of water resource in deep aquifers, in particular, in a context of climate and recharge change.

[3] Since the pioneering work of Toth [1963], who derives the distribution of groundwater flow in two-dimensional systems, several theoretical studies have been carried out to derive groundwater flow as a function of the permeability and topography structures of continents. Analytic and numerical solutions have been derived by assuming that the water table is equal to the topography [e.g., Cardenas, 2007; Craig, 2008; Dahl et al., 2007; Freeze and Witherspoon, 1967; Jiang et al., 2011; Winter, 1978; Zijl, 1999]. These studies have shown the complexity of the nested flow structures, the importance of location of the discharge zones, and the sensitivity of the deep flows given specific water table surfaces. More quantitative analyses, however, require a full model of the free water surface where the recharge is imposed rather than deduced from the surface level. Fixing the water table, either to topography or below, actually completely determines the flow distribution at any depth and the overlying recharge [Liang et al., 2012; Sanford, 2002].

[4] The spatial distribution of recharge and discharge areas and their variations with geologic or climatic variables are the key controls of groundwater pathways. 


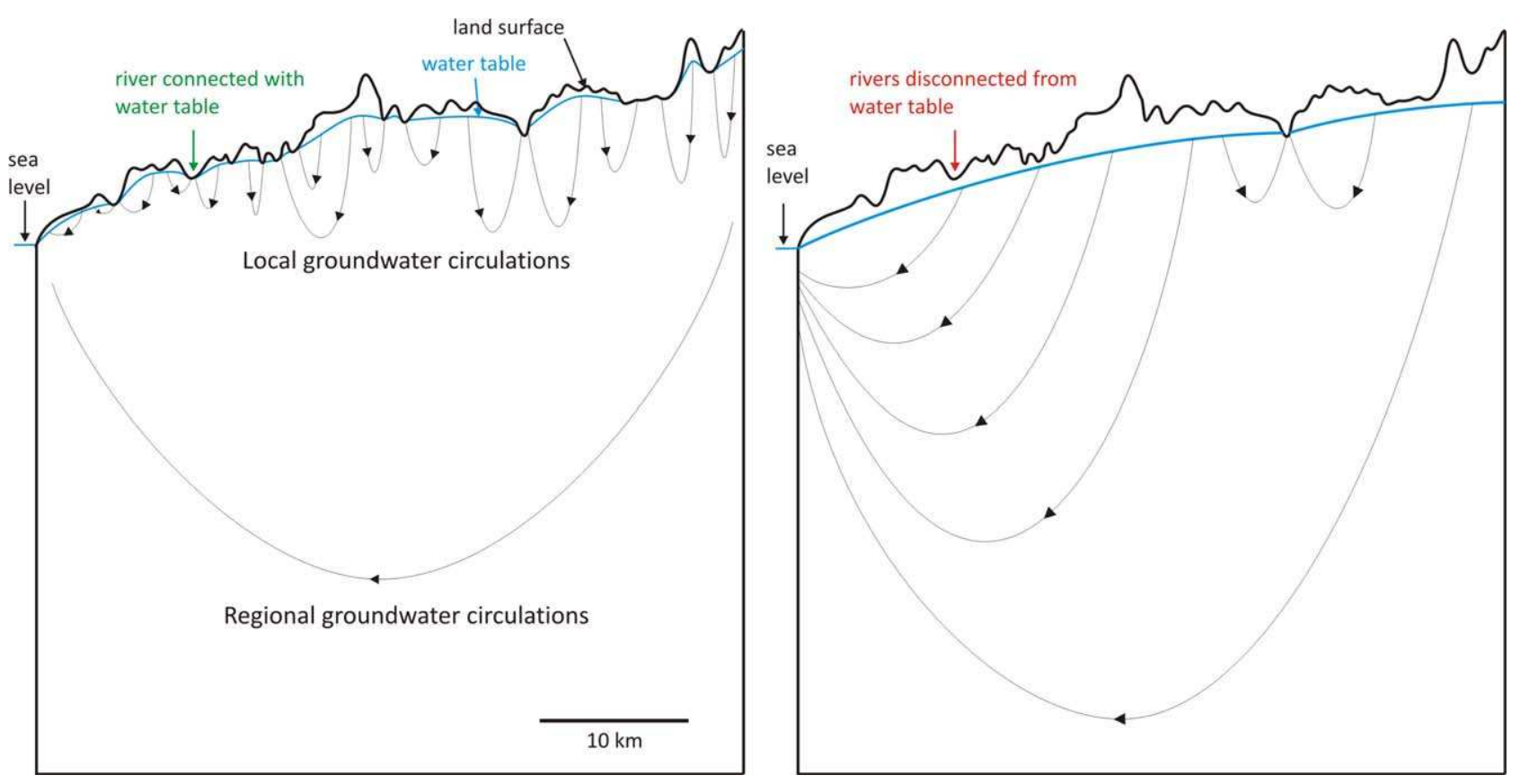

Figure 1. Conceptual model of deep groundwater circulation under (a) high recharge rates and (b) low recharge rates.

Different discharge zone spatial distributions may significantly modify the structure of groundwater circulations, as discussed by Haitjema and Mitchell-Bruker [2005], and shown conceptually in Figure 1. Under high recharge rates (Figure 1a), subsurface streamlines are generally short between recharge areas, which form a very dense hydrographic network. Under lower recharge rates (Figure 1b), disconnection of rivers induces a general increase of the groundwater streamline lengths down to lowland discharge areas. In this context, simple boundary conditions, such as prescribed hydraulic heads, are much too restrictive in systems where the spatial distribution of discharge zones is very sensitive to recharge conditions.

[5] Many case studies involving surface-subsurface interactions have been carried out either locally or at the scale of small catchments (see Fleckenstein et al. [2006], Frei et al. [2009], Goderniaux et al. [2011], Jones et al. [2008], Scibek et al. [2007], and Sophocleous [2002] for some examples at the catchment-scale). These studies focus mostly on shallow (usually less than $100 \mathrm{~m}$ ) and very permeable aquifers; they aim at characterizing the water balance terms (groundwater discharge, surface water infiltrations, and groundwater levels in relation with streams). An important issue for these studies is to fix or calculate the recharge areas acting as boundary conditions of the groundwater flow.

[6] In this study, we focus on the study of the compartmentalization of aquifers at the continental scale as a function of climate. Our objective is to quantify the 3-D partitioning between shallow aquifers, which are likely connected to adjacent rivers, and deeper ones, and the way their characteristics are modified with recharge.

[7] To reach these targets and considering the requirements discussed earlier, we develop a model that fulfills several conditions. According to the results of Toth [1963], which show that deep flow occur at the regional scale concurrently to shallow circulations, the model has been implemented at the regional scale, including different catchments. Groundwater flows are considered in three dimensions, which is very important in this case because water circulations may be organized across several scales, from small scale transfers within first-order basins, to regional intercatchments transfers, and distributed between shallow and deep aquifers, including horizontal and vertical flows. The model uses a flexible way to represent water exchanges between subsurface and surface compartments as a function of recharge and without imposing a priori recharge and discharge zones. The model is subsequently used to simulate flow pathways and transit times (total time from inlet to outlet, Cornaton and Perrochet [2006]) within the system. Results are used to implement a compartment model of the aquifer and to calculate the volumes related to these compartments as a function of recharge. These scales, dimensions, and improvements are usually not considered simultaneously in previous work. They provide new insights and an efficient way to analyze 3-D water transfers and to quantify the recharge partitioning between different subsurface compartments.

\section{Model Implementation}

[8] The numerical model has been developed to simulate deep groundwater flow for a synthetic case. The objective is not to represent real geological conditions but to identify the key parameters and the general structure of groundwater circulations in generic shallow and deep aquifers. For convenience and to include the whole complexity inherent to a topographic surface, we use a real digital elevation model as a guideline for the study. Stresses applied as input of the model are variable in order to test different configurations. The modeled area $\left(1385 \mathrm{~km}^{2}\right)$ includes four main basins (Aven, Belon, Isole, and Ellé) in Brittany and other 


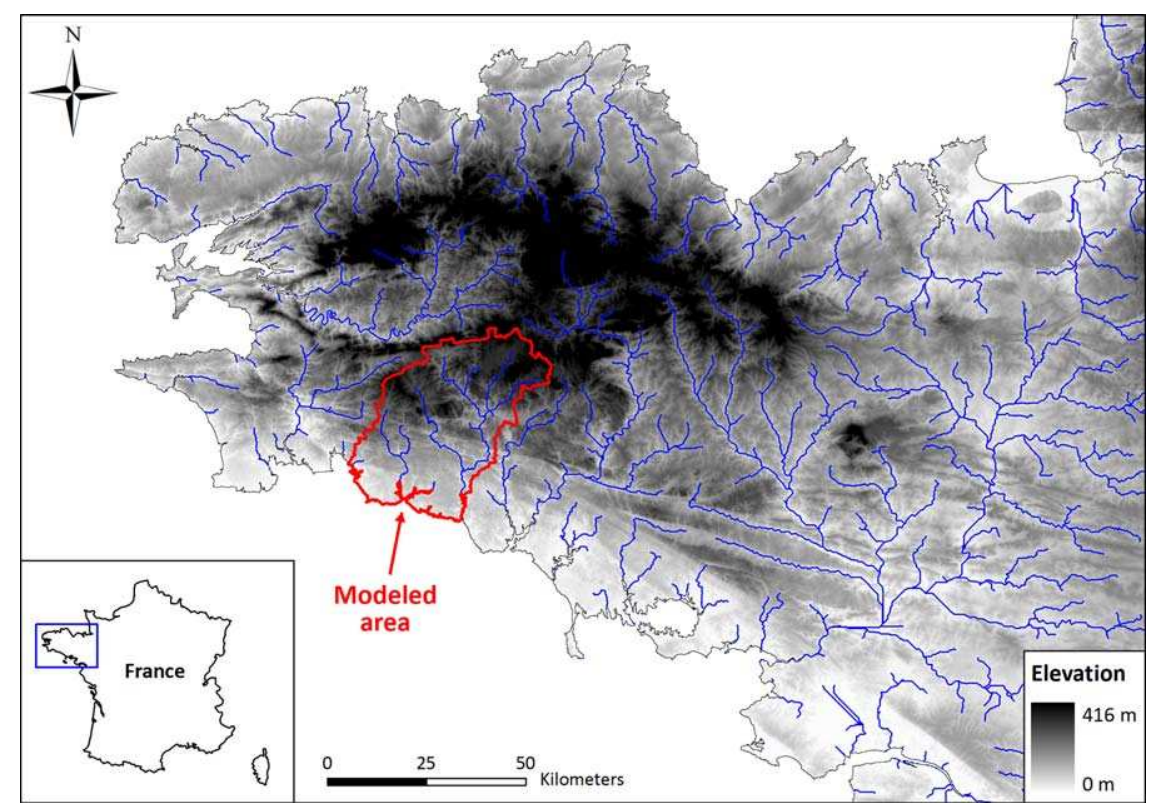

Figure 2. View of the modeled area at the scale of the "Brittany" region.

smaller rivers flowing directly into the sea or estuaries (Figure 2). The limits of the area correspond to the hydrographical limits of the four main basins and about $100 \mathrm{~km}$ of coastlines including estuaries. The modeled area can be described as "at the scale the Brittany peninsula," as the size of the model is approximately half of the distance between the northern and southern coasts, and the elevations cover the whole range of altitudes in Brittany (from 0 to $\sim 400 \mathrm{~m}$ ) (Figure 2). Figure 3 shows the relation "slope-drainage area," calculated using a digital elevation model (DEM) with a resolution of $25 \mathrm{~m}$. This curve is achieved considering surface drainage only and enables to characterize and compare different topographies by quantifying specific parameters. For each point of this DEM, the slope and surface area that drains through this point are calculated. The slope is averaged for different area intervals and plotted in a log-log diagram. The decreasing part of the curve can be fitted by two straight lines, which intersect to give an estimate of the first-order catchment area [Ijjasz-Vasquez and Bras, 1995; Montgomery and Foufoulageorgiou, 1993]. Applying this technique for the modeled basins gives an area of approximately $0.5 \mathrm{~km}^{2}$. The large range of scales between the first-order catchment and the size of the model allows the representation of both local and regional water transfers. The vertical extension of the modeled area ranges from the ground surface to $-1000 \mathrm{~m}$ below sea level.

[9] The area is discretized using finite difference square cells, with lateral dimensions of $200 \times 200 \mathrm{~m}$, and simulations are performed with Modflow 2005 [Harbaugh et al., 2000]. Vertically, 30 finite difference layers are used from the ground surface to the bottom of the model. Each layer is composed of 34,617 cells, leading to a total number of cells around $10^{6}$. The height of the cells increases from the ground surface to the bottom of the model as a function of the total vertical thickness of the area. Boundary conditions have been specified to all external limits of the model. A "specified head" boundary condition is prescribed to the nodes located along the coastline in the first cells layer (Figure 4b) [Harbaugh et al., 2000]. A "no-flow" boundary condition is prescribed to all other lateral limits and to the bottom of the model. A "drain" boundary condition (headdependent flux) [Reilly, 2001] is prescribed to all top faces corresponding to the ground surface. Water leaves the system only when the hydraulic head is higher than ground surface elevation. The outward flux is calculated as the difference between hydraulic head and surface elevation multiplied by a drain conductance $K_{D}$. If the hydraulic head is below the ground surface, there is no flow leaving the groundwater domain. In this case, the conductance is uniformly specified to a large enough value so that, when the

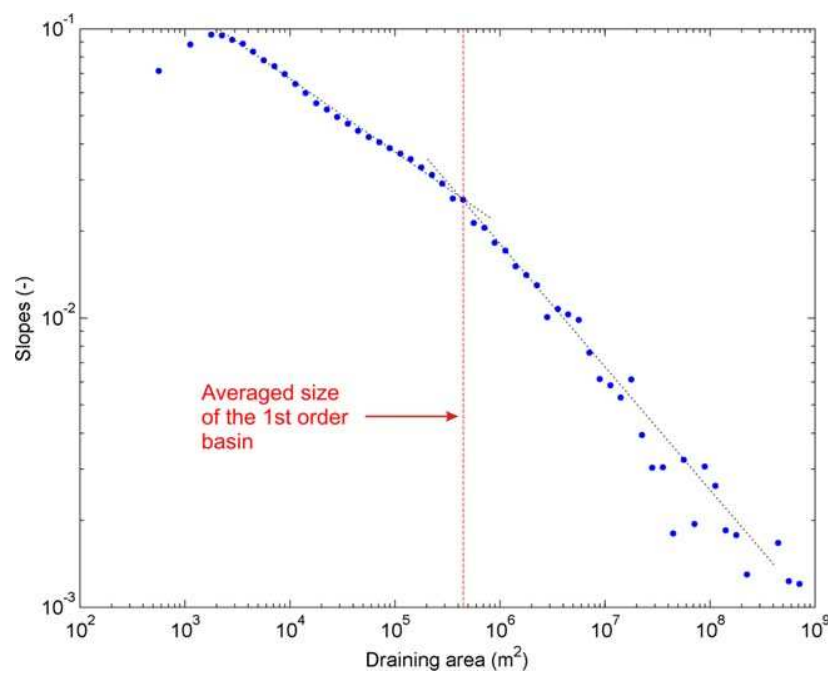

Figure 3. Averaged slope as a function of the upward drainage area calculated for the modeled area. The red dotted line shows the size of the first-order basin. 

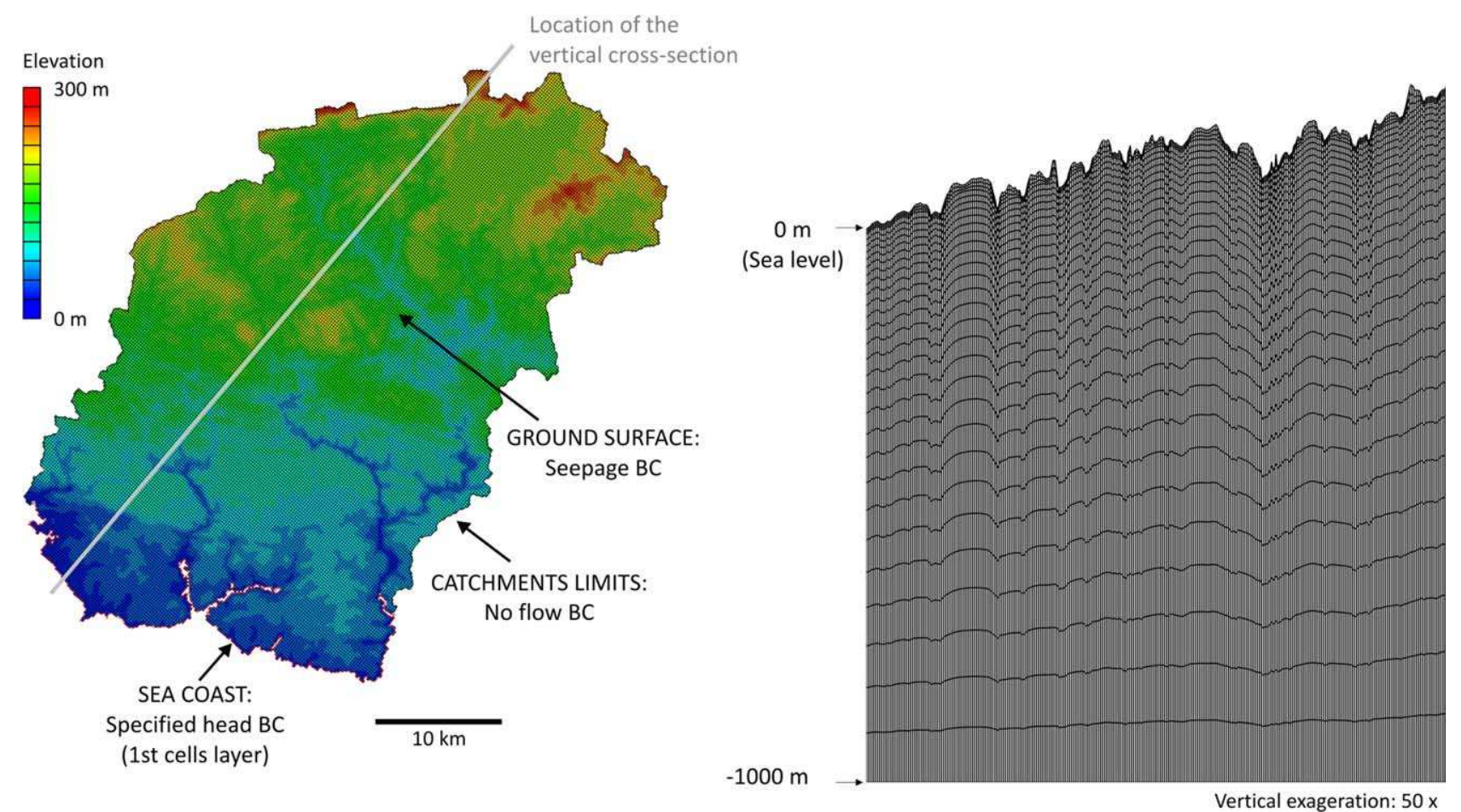

Figure 4. (a) Plan view of the area, elevation, and boundary conditions and (b) vertical cross section.

water table reaches the ground surface, the computed head stays very close to the surface elevation. This kind of boundary condition conceptualizes the topography as a drainage system where rivers are fed by groundwater. In Brittany, this assumption is verified in most cases, except for very specific topography configurations and very low recharge rates. The most important advantage is that the river network is not prescribed along specified lines but spatially dependent on simulated groundwater conditions and recharge. When the water table is below the ground surface, the inflow rate is the recharge rate, which is imposed uniformly on the top faces of the system.

[10] Parameters of the model correspond to the hydraulic conductivity and porosity. Results are presented here for a homogeneous system. The unique value of hydraulic conductivity is adjusted so that the number and position of active draining cells, simulated with the current and reasonably well-known stationary recharge of $300 \mathrm{~mm} / \mathrm{yr}$, correspond approximately to the current hydrographical network, which is considered as groundwater discharge zones (see above). This approach is possible, thanks to the specific assumptions of the model, where the water table and river network are not prescribed but dependent on recharge and simulated groundwater conditions. This calibration led to a homogeneous hydraulic conductivity of $10^{-6} \mathrm{~m} / \mathrm{s}$.

[11] The model is used to simulate groundwater flow over the whole domain and to calculate discharge areas, fluxes, pathway lengths, and normalized transit time. Pathway length and transit time are calculated using "particle tracking" [Pollock, 1994]. Since all transit times depend linearly on the porosity, we normalize them by the porosity ("time/porosity"). The hydrogeological model is further simulated and analysed for different recharge rates under steady-state conditions. The range of investigated recharge between 20 and $500 \mathrm{~mm} / \mathrm{yr}$ is intentionally large to study contrasted configurations.

\section{Results}

[12] Figures 5 and 6 show, respectively, the evolution of groundwater levels and discharge zones (the area where groundwater exfiltrates into the surface domain) as functions of recharge. Logically, groundwater levels and discharge area increase with input recharge. Under a high recharge of $500 \mathrm{~mm} / \mathrm{yr}$, groundwater levels are strongly influenced by topography, and discharge areas cover $39 \%$ of the total area. On the contrary, with a low recharge of 20 $\mathrm{mm} / \mathrm{yr}$, interception of the groundwater surface by topography is limited to the three main rivers, which have a direct implication on the length of water pathways from recharge to discharge areas. The blue areas on Figure 6 represent the discharge zone of the aquifer that corresponds to segments of the rivers. These segments mainly occur as a continuous network, except at low recharge, where missing parts are observed. These missing segments correspond to streams disconnected from the water table (encircled in red on Figure 6) and where river leaks into aquifers, which is not taken into account by the model. Even at low recharge rate, the density of disconnections remains very limited, and rivers mainly behave as groundwater drainage elements

[13] Water pathways have been calculated by using the groundwater model and a standard particle tracking method. One particle has been placed in each of the 34,617 cells at the top of the water table, and the pathway to the discharge point has been simulated. The spatial distribution 

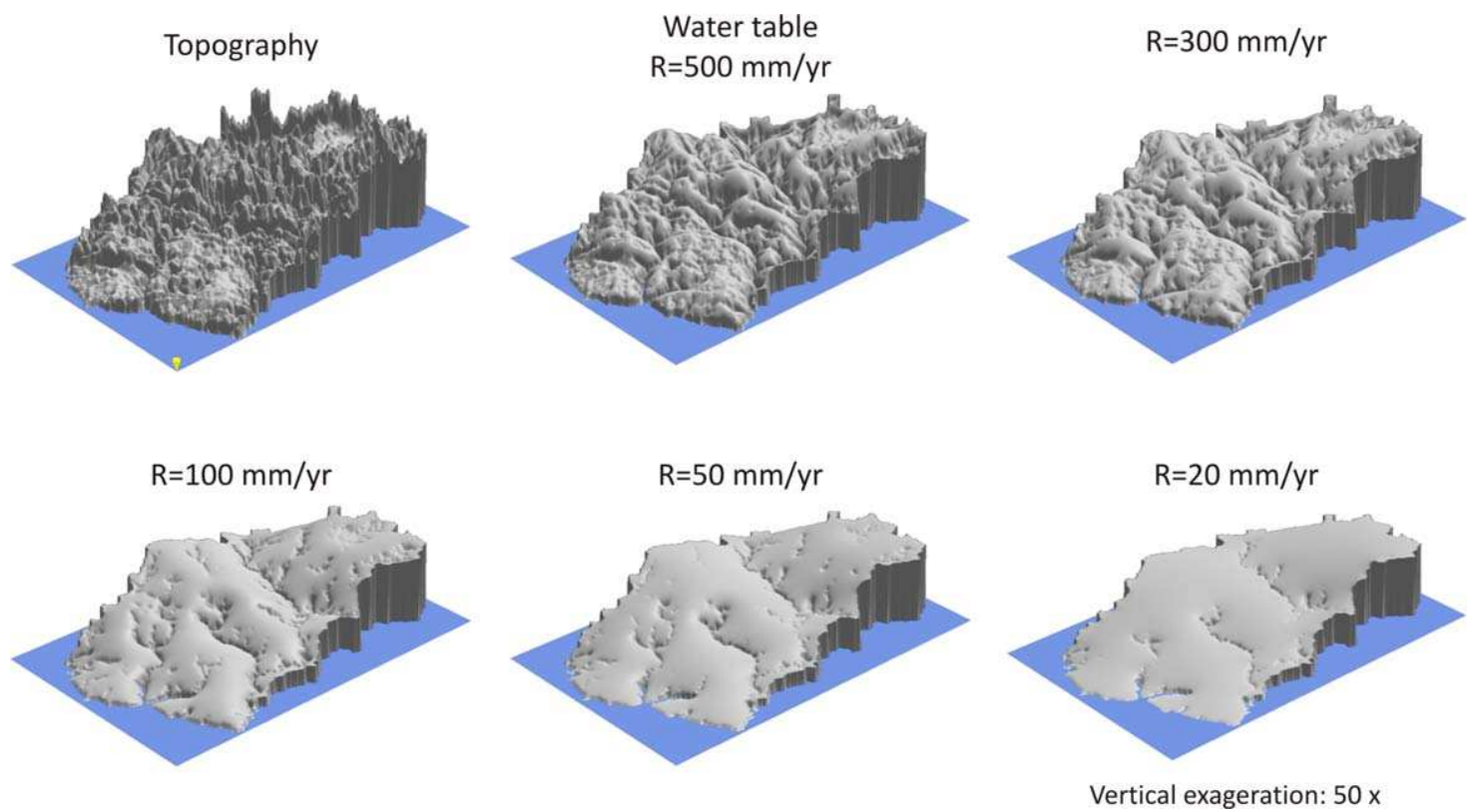

Figure 5. Evolution of groundwater levels as a function of recharge.

of the pathway lengths is shown in Figure 7 for different recharge rates. Data are plotted for each particle starting point. The graphs show that the pathway lengths logically increase from the discharge areas to the topographic crests. For high recharge rates, most of the pathways are shorter than $1 \mathrm{~km}$, emphasizing the role of the dense river network in delineating small hillslope catchments. Pathways get longer as recharge rates decrease. For a recharge of $20 \mathrm{~mm} / \mathrm{yr}$, a significant part of the pathways are longer than $10 \mathrm{~km}$, and larger hydrogeological catchments are visible.

[14] The distributions of particles transit times over the whole area show a similar structure as distance pathway distributions, as time is strongly correlated to distance for the case of homogeneous permeability conditions assumed here. Normalized transit times (time divided by porosity) typically vary from 0 to 50,000 years for a recharge of 500 $\mathrm{mm} / \mathrm{yr}$, and from 0 to 300,000 for a recharge of $20 \mathrm{~mm} / \mathrm{yr}$. This is explained by the overall increase of pathway lengths and decrease of fluxes when recharge decreases. Figure 8 presents a vertical cross-section of the aquifer (location indicated in Figure 4), indicating at each point the transit time of the particle intercepting it. The light blue, yellow, and red colors correspond to finite difference cells intercepted by particles with normalized total transit time (time from recharge to discharge) lower than 10,000 years, between 10,000 and 40,000 years, and greater than 40,000 years, respectively. The dark blue color is related to the unsaturated part of the domain. At high recharge rates, we observe a predominance of small hydrogeological catchments, as in Figures 5 and 7. Water circulations are more local, vertical, and deeper than at lower recharge rates. At low recharge rates, catchments become wider, and circulations are mainly regional and more horizontal. These graphs constitute a variant compared to the representations provided by Toth [1963], accounting for recharge variations and free water table, as well as full 3-D processes. Note that Figure 8 only shows 2-D sections and that groundwater flow can be perpendicular to these sections. When going deeper in the system, circulation cells are enlarged and their shape thoroughly changes. This is, for example, quite visible for the case of a recharge equal to $100 \mathrm{~mm} / \mathrm{yr}$ (Figure 8), and this is explained by 3-D topography and flow transfers.

\section{Interpretation With a Two-Compartment Model}

[15] The distributions of pathway lengths and normalized transit times are also shown in Figures 9 and 10, where the probability density function is plotted against different classes of length and time. Studying the transit time distributions allows analyzing water transfers and volumes within aquifers. As further discussed in section 5, different transit time statistical models have been developed in the past and are typically used to interpret environmental tracers or stable isotopes time series [Maloszewski and Zuber, 1982, 1996; McGuire and McDonnell, 2006]. Here, the focus is somewhat different. Experimental transit time distributions are used as a blueprint of the organization of circulations and the compartmentalization of aquifers.

[16] Transit time and pathway length distributions display two different regimes (Figure 9). The first regime corresponds to short circulations within first-order basins $\left(\sim 0.5 \mathrm{~km}^{2}\right) \quad\left(\right.$ length $<1500 \mathrm{~m}, \quad$ time/porosity $<5 \times 10^{3}$ years). The second regime corresponds to more regional and deeper circulations well modeled by an exponential decrease (straight line in Figure 9). For the transit time distribution, the exponential distribution is characteristic of transfers within homogeneous aquifers with uniform recharge [Gelhar and Wilson, 1974; Haitjema, 1995; Lerner and Papatolios, 1993]. The idea of this study is to assume that the two regimes of the transit time distribution (Figure 9) identify two different compartments. The first one is linked to the faster component and closely related to 

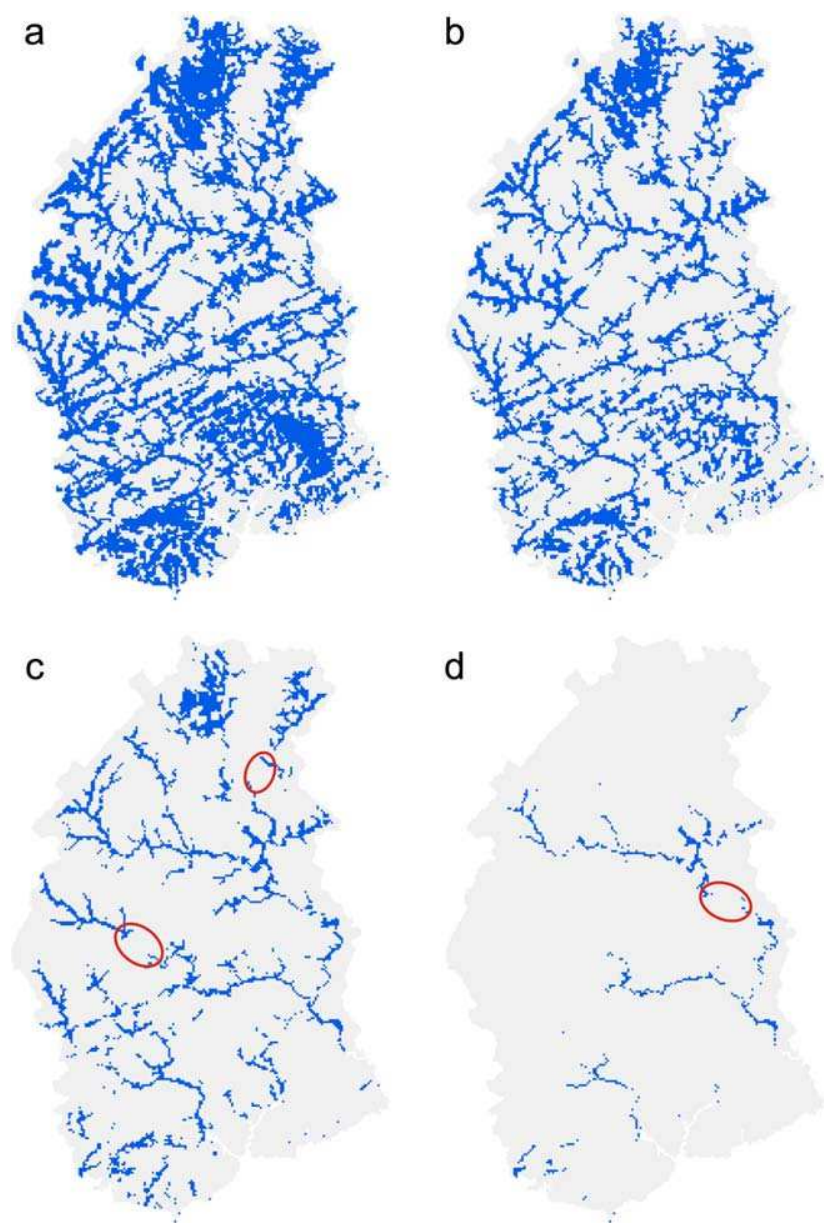

Figure 6. View of the effective draining cells in function of different recharge values $(R)$. Red circles correspond to area where a significant river section becomes perched above the water table. (a) $R=500 \mathrm{~mm} / \mathrm{yr}$, draining cells: $39 \%$ of the area, (b) $R=300 \mathrm{~mm} / \mathrm{yr}$, draining cells : $25 \%$ of the area, (c) $R=100 \mathrm{~mm} / \mathrm{yr}$, draining cells: $10 \%$ of the area, and (d) $R=20 \mathrm{~mm} / \mathrm{yr}$, draining cells : $2 \%$ of the area.

topography. The second one is linked to the slower component, more characteristic of the whole reservoir, with more regional and deeper water transfers. The transit time distributions $f_{1}(t)$ and $f_{2}(t)$ issued by these two compartments are represented by the two terms of equation (1), which is used to fit the full transit time distributions $f(t)$.

$$
f(t)=\beta_{1} \times f_{1}(t)+\beta_{2} \times f_{2}(t)
$$

where $\beta_{1}$ and $\beta_{2}$ give the proportion of "fast" and "slow" components relatively to the whole distribution, and their sum is equal to 1 (equation (2)). Considering the interpretation in two different compartments, both terms have occurrence from 0 to $+\infty$ but highly different probabilities.

$$
\int_{0}^{+\infty}\left(\beta_{1} \times f_{1}(t)+\beta_{2} \times f_{2}(t)\right) \times \mathrm{dt}=\beta_{1}+\beta_{2}=1 .
$$

[17] According to previous results, the slow term $f_{2}(t)$ corresponds to the exponential model of equation (3), where $\mathrm{Tc}_{2}$ is the characteristic time of the distribution.

$$
f(t)=\beta_{1} \times f_{1}(t)+\frac{\beta_{2}}{\mathrm{Tc}_{2}} \times \exp \left(\frac{-t}{\mathrm{Tc}_{2}}\right) .
$$

[18] The fast term $f_{1}(t)$ is not a simple exponential as $f_{2}(t)$ but a more complex function resulting from the diversity of the local watersheds (Figure 9). Its precise shape likely comes from the details of the topography as well as from the nested circulation structure close to the topography. In Figures 9 and 10, the second slow regime of both the pathway length and the transit time distributions has been fitted by the exponential model. The characteristic length $\mathrm{Lc}_{2}$ (from the exponential fit) increases as recharge rates decrease, and ranges from $1.6 \mathrm{~km}$ to $8 \mathrm{~km}$ for recharge rates of 500 and $20 \mathrm{~mm} / \mathrm{yr}$, respectively (Table 1). This confirms the longer paths observed in Figure $7 d$, due to the disconnection of upstream areas. The normalized characteristic time $\mathrm{Tc}_{2}$ (time divided by porosity) increases from 8300 to 57,000 years, for recharge rates decreasing from 500 to $20 \mathrm{~mm} / \mathrm{yr}$ (Table 1), because of velocity reductions and pathways lengthening. The weight of the second term $\beta_{2}$, which gives the proportion of recharge attributed to the slow or regional compartment, increases as total recharge decreases, and ranges from 0.22 to 0.90 . For small recharge rates and reduced discharge zone area, regional circulations
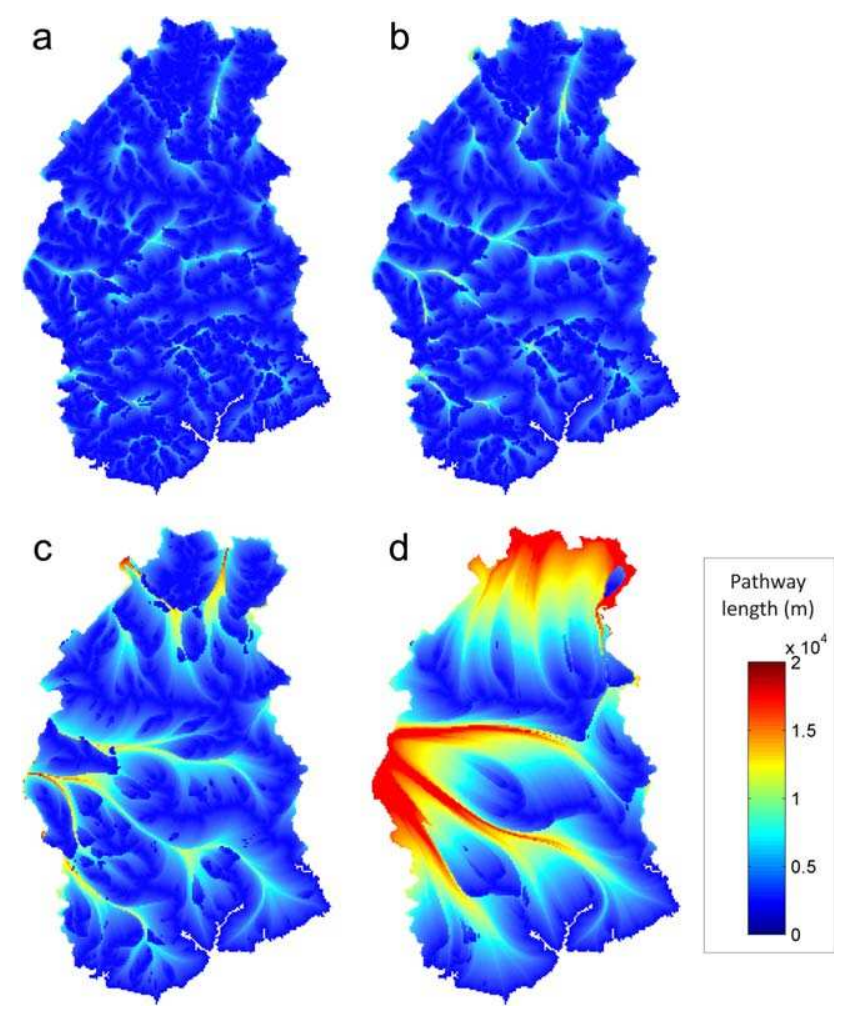

Figure 7. Spatial distribution of groundwater pathway lengths $(\mathrm{m})$ across the modeled area and according to different input recharge rates. Data are plotted for each particle starting point. (a) $R=500 \mathrm{~mm} / \mathrm{yr}$, (b) $R=300 \mathrm{~mm} / \mathrm{yr}$, (c) $R=100 \mathrm{~mm} / \mathrm{yr}$, and (d) $R=20 \mathrm{~mm} / \mathrm{yr}$. 

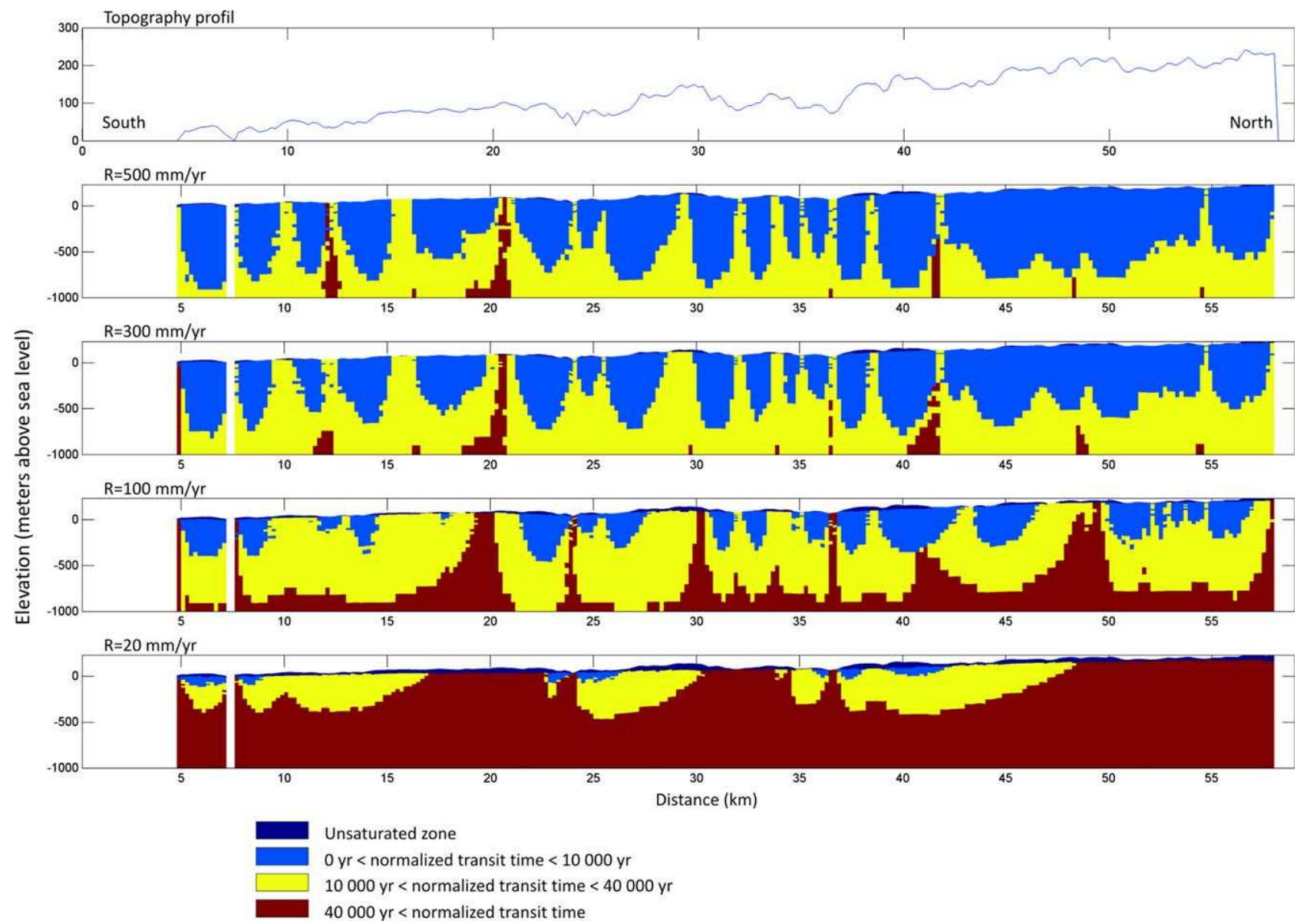

Figure 8. Visualization of volumes intercepted by particles with normalized transit times included in different intervals and evolution as a function of the total recharge flux. Results are shown for the cross section highlighted in Figure 4. Top figure represents the topographic evolution on the cross section.
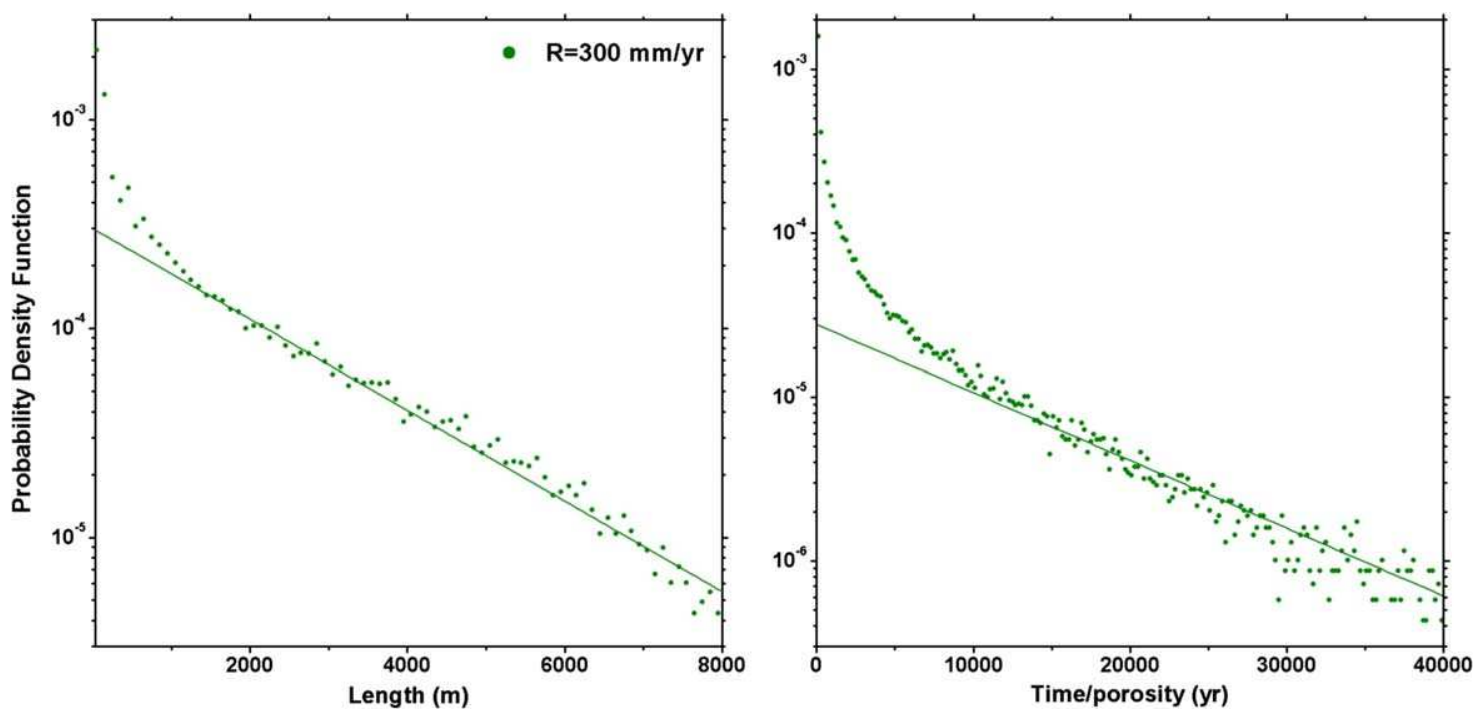

Figure 9. Probability density functions of pathway length and transit times for a recharge of $300 \mathrm{~mm} / \mathrm{yr}$, calculated using the model and particle tracking. A single particle has been placed at the top of the water table in each of the 34,617 cells covering the domain, and the pathway to the discharge point has been simulated. Distributions of (a) pathway lengths and (b) travel times. 

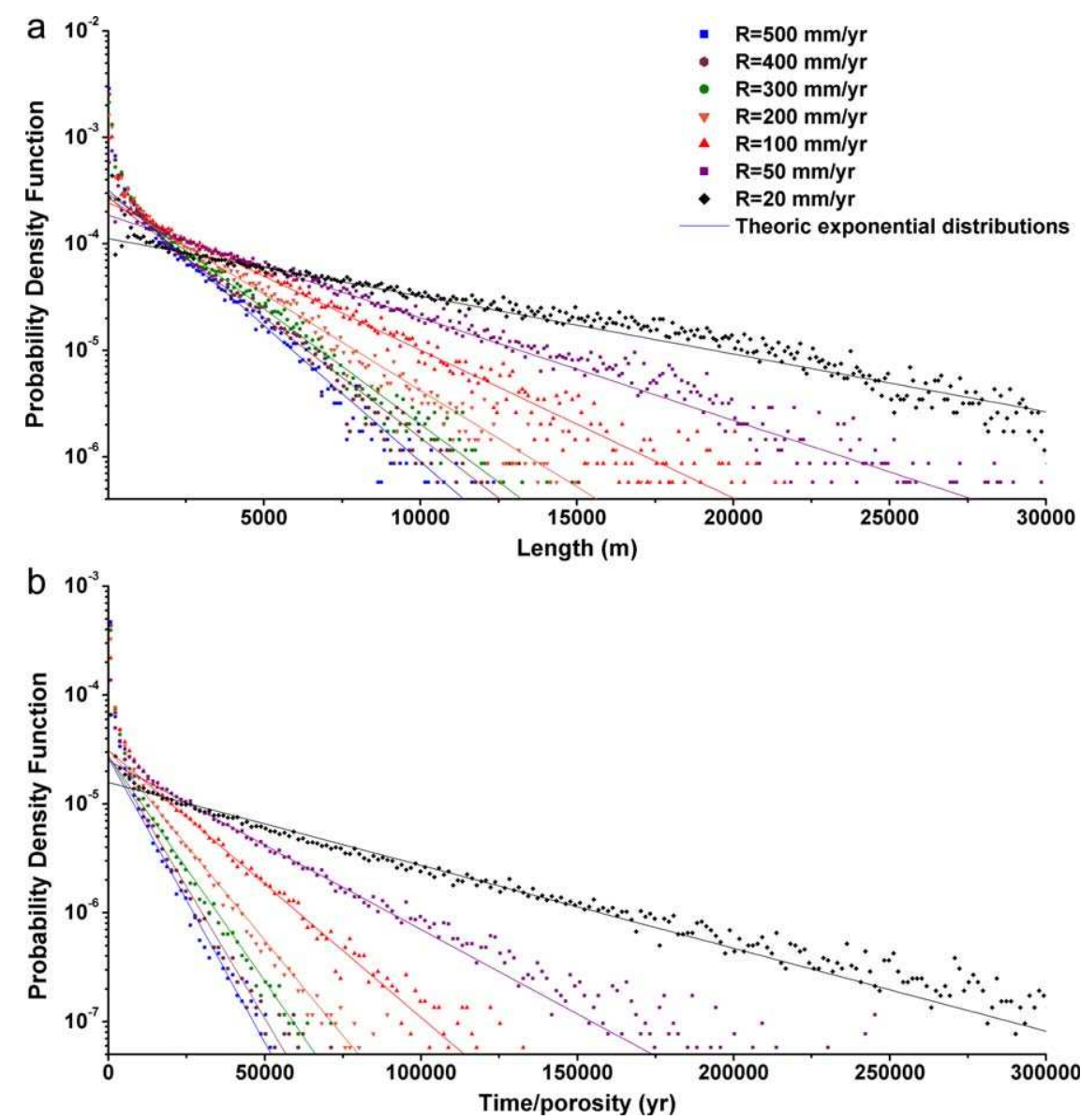

Figure 10. Probability density functions of pathway length and transit times, calculated using model and particle tracking. A single particle has been placed at the top of the water table in each of the 34,617 cells covering the domain, and the pathway to the discharge point has been simulated. Distributions of (a) pathway lengths and (b) travel times.

dominate and the total distribution may tend to a simpler exponential model (Figure 10).

[19] This two-compartment model, fitted to the experimental data, provides information on the organization of groundwater circulations in the modeled domain. It gives insights about the evolution of characteristic values and, more interesting, about the partitioning of flows between the two compartments. The volume of the second slow compartment $\mathrm{Vc}_{2}$ can be approximated from the knowledge of $\beta_{2}$ and $\mathrm{Tc}_{2}$ in the following way. Equations (2) and (3) partition the flow into the two compartments. The flow through the second compartment is simply expressed by

$$
Q_{i}=A_{i} \times R=\beta_{i} \times A_{T} \times R
$$

where
[20] $Q_{i}$ : recharge associated to compartment $i\left[L^{3} T^{-1}\right]$;

[21] $R$ : recharge flux over the domain $\left[L T^{-1}\right]$;

[22] $A_{T}$ : total recharge area $\left[L^{2}\right]$;

[23] $A_{i}$ : recharge area associated to distribution $i$ or area where input particles belong to distribution $i\left[L^{2}\right]$.

[24] Assuming along the exponential model derived in simple homogeneous watersheds [Haitjema, 1995] that the residence time is, as a first approximation, the volume of the aquifer divided by the flow through it, it directly gives $\mathrm{Vc}_{2}$ as

$$
\mathrm{Vc}_{2}=Q_{2} \times \mathrm{Tc}_{2}
$$

where $\mathrm{Vc}_{2}\left[L^{3}\right]$ is the aquifer volume attributed to the second compartment.

\begin{tabular}{|c|c|c|c|c|}
\hline & $R=500 \mathrm{~mm} / \mathrm{yr}$ & $R=300 \mathrm{~mm} / \mathrm{yr}$ & $R=100 \mathrm{~mm} / \mathrm{yr}$ & $R=20 \mathrm{~mm} / \mathrm{yr}$ \\
\hline Characteristic length: $\mathrm{Lc}_{2}(\mathrm{~m})$ & 1,700 & 2,000 & 3,125 & 8,000 \\
\hline $\begin{array}{l}\text { Normalized characteristic time } \\
\text { (time/porosity): } \mathrm{Tc}_{2}(\mathrm{yr})\end{array}$ & 8,300 & 10,500 & 17,700 & 57,000 \\
\hline Proportion of particles: $\beta_{2}$ & 0.22 & 0.29 & 0.55 & 0.90 \\
\hline
\end{tabular}

Table 1. Characteristic Values of Pathway Length $\left(\mathrm{Lc}_{2}\right)$, Normalized Transit Time $\left(\mathrm{Tc}_{2}\right)$, and Proportion $\left(\beta_{2}\right)$ for Distribution 2 

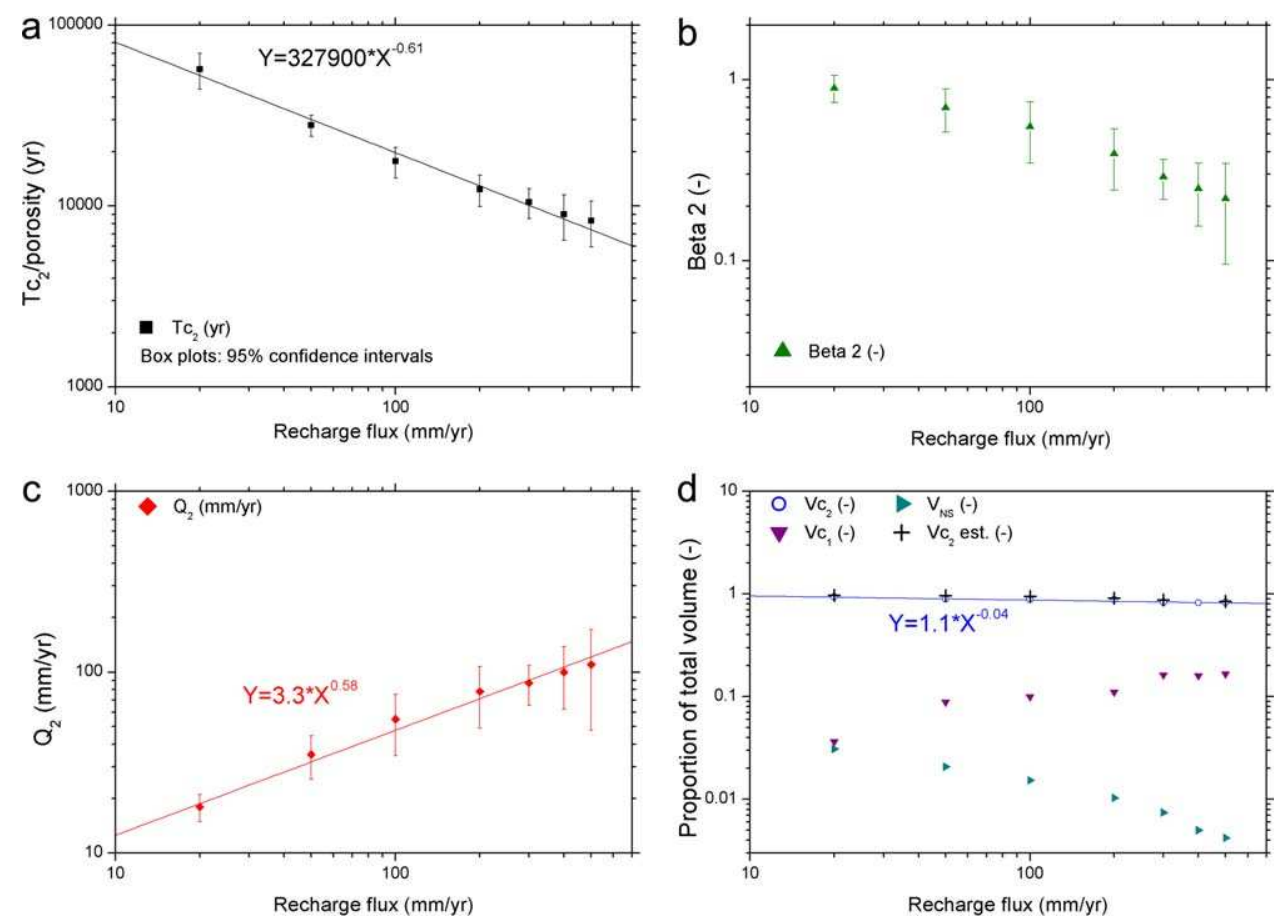

Figure 11. Evolution of (a) the characteristic time $\mathrm{Tc}_{2}$, (b) $\beta_{2}$, (c) recharge flow rate $Q_{2}$ and (d) the volume proportion corresponding to the different compartments as a function of the total recharge flux $R$.

[25] Using this model for the interpretation of the results presented in Figure 10 gives the evolutions of $\mathrm{Tc}_{2}, \beta_{2}, Q_{2}$, and $\mathrm{Vc}_{2}$ according to the recharge flux (Figure 11, log-log diagrams). $\mathrm{Vc}_{2}$ is expressed as a proportion of the total aquifer volume. The characteristic time $\mathrm{Tc}_{2}$ and the coefficient $\beta_{2}$ decrease as recharge flux increases, as already shown in Figures 9 and 10 and Table 1. The absolute flow rate associated to the second deep compartment $\left(Q_{2}\right)$ increases with recharge flux. The parameter evolutions of $\mathrm{Tc}_{2}$ and $Q_{2}$ with recharge $R$ are best fitted by power laws, as shown in Figure 11, $\mathrm{Tc}_{2} \sim R^{\alpha}$ and $Q_{2} \sim R^{\beta}$ with exponents equal to $\alpha=-0.61$ and $\beta=0.58$, respectively. The proportion of recharge feeding the second compartment relatively decreases with increasing recharge as $Q_{2} / R \sim R^{\beta-1}$. According to equation (5), the volume attributed to the second compartment evolves as a product of two functions $V_{2}=Q_{2} \times \mathrm{Tc}_{2}=\sim R^{\alpha+\beta}=\sim R^{-0.03}$ (Figure 11). This means that recharge only marginally modifies the volume attributed to the deep/slow compartment. Figure $11 \mathrm{~d}$ also shows the volume of the partially saturated zone $\left(V_{\mathrm{NS}}\right)$, included between the water table and the ground surface, and the volume of the fast or local compartment, calculated as the complementary part relatively to the total volume (equation (6)).

$$
V_{\text {total }}=\mathrm{Vc}_{1}+\mathrm{Vc}_{2}+V_{\mathrm{NS}} .
$$

[26] To corroborate the global organization of circulations in two compartments, effective volumes have been calculated on the finite difference grid using the transit time map established on the pathways of the particles (Figure 8). Each cell is given the total transit time of the particle crossing it. The affectation of the cell to the fast and slow volume may be ambiguous for transit times around the crossover between the two distributions. To resolve this ambiguity, we take the approximation that the two volumes are sharply separated. The volume $\mathrm{Vc}_{2 \mathrm{est}}$ of the "deep-slow" compartment corresponds to the cells intercepted by the $\beta_{2}$ proportion of particles having the highest transit times. Figure $11 \mathrm{~d}$ shows that $\mathrm{Vc}_{2 \text { est }}$ approximates $\mathrm{Vc}_{2}$ well. The slight overestimation of a few percents comes from the sharp separation assumption. The volumes attributed are displayed on Figure 12 on the finite difference grid, for different values of the total recharge flux. The graphs correspond to the vertical cross section indicated in Figure 4 and already used in Figure 8. The light blue and yellow colors correspond to cells intercepted by particles from both terms of the two-compartment model (equation (1)). The red color corresponds to cells crossed by particles from both compartments and the dark blue color to the unsaturated part of the domain. On these graphs, the volumes associated to the first term of equation (1) correspond to local transfers and are located in the vicinity of discharge points. The volume $\mathrm{Vc}_{2 \text { est }}$ of the second exponential term is regional and includes topographic crests. As shown in Figure 11d, the volume associated to "regional" water transfer only increases slightly with decreasing recharge flux. The shape of the circulation cells is however modified, with wider cells associated to low recharge rates.

\section{Discussion and Implications}

\subsection{Two-Compartment Model}

[27] In this study, a two-compartment model (equation (1)) is used to fit the transit time distributions calculated 


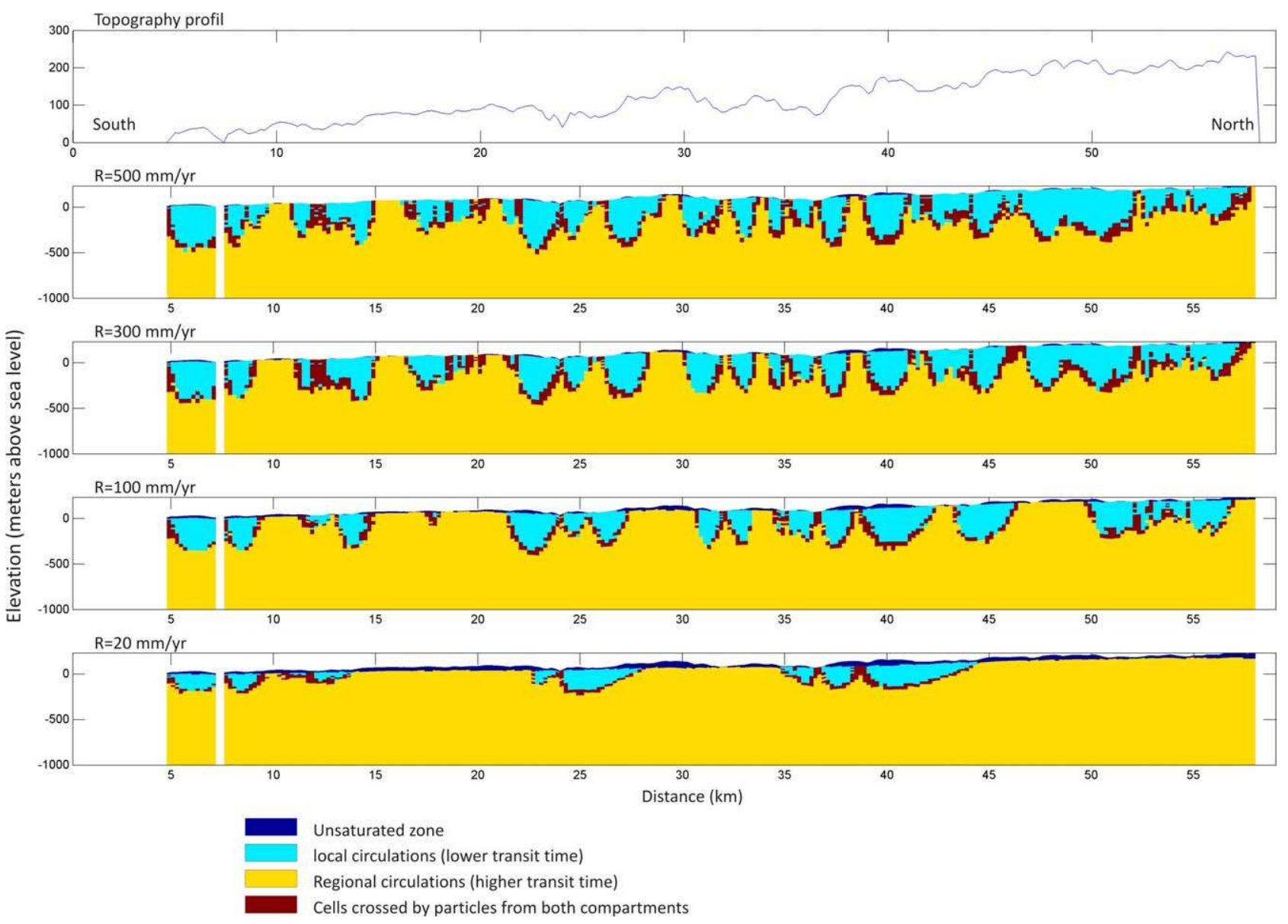

Figure 12. Approximated volumes corresponding to both terms of equation (1) as a function of the total recharge flux. Results are shown for a cross section visualized in Figure 4.

experimentally with the numerical model. Other statistical models are available to characterize transit time distributions [McGuire and McDonnell, 2006]. Commonly used distributions, such as the "piston-flow," "exponential piston-flow," "exponential," "linear" and "dispersion" model, are discussed in their context and compared by Maloszewski and Zuber [1982, 1996]. Haitjema [1995] performed catchment-scale modeling work and found exponential transit time distributions. Luther and Haitjema [1998] conclude that these distributions are valid for confined and unconfined aquifers in homogeneous or piecewise heterogeneous aquifers, as long as the ratio of volume to recharge remains uniform, based on 2-D numerical simulations with river-aquifer interactions implemented as "specified head" boundary conditions on a fixed and simple river network. They also show how the shape of the residence time distribution can be modified when aquifer heterogeneities are few and distinct. Kirchner et al. [2000, 2001] rather suggested gamma law to model transit time distributions and justified it with an advection-dispersion model. Fiori and Russo [2008] and Fiori et al. [2009], who performed complex, three-dimensional numerical simulations at the scale of a hillslope, also concluded on gamma distributions to represent transit time in the hillslope. Cardenas [2007] carried out physically based numerical simulations in a vertically two-dimensional domain representing the Toth problem [Toth, 1963] and calculated transit time distributions characterized by a power law behavior. These theoretical models are commonly used in specific catchments, using environmental tracers or stable isotopes to estimate mean transit times or perform hydrograph separation [Leray et al., 2012; McGuire and McDonnell, 2006]. Models are generally used to represent observed tracer time series in river or groundwater baseflow and tracer input at the level of the ground surface [e.g., Asano et al., 2002; Maloszewski et al., 1983; Rodgers et al., 2005; Uhlenbrook et al., 2002]. Other studies also apply and compare a combination of different models to fit tracer time series [e.g., McGuire et al., 2005; Weiler et al., 2003].

[28] Some of these available models, such as the pistonflow, linear, or simple exponential model, are clearly not usable in our study because their shape does not correspond to what is actually observed in this case. The more flexible gamma model, as used by Kirchner et al. [2000] and Fiori and Russo [2008], could possibly be used, but this model does not differentiate processes or reservoirs. The twocompartment equation (equation (1)) offers several advantages. First, it is consistent with the exponential distribution of long transit times and uses a limited number of parameters. Second, it offers an efficient way to differentiate and 
quantify two different compartments and circulations related to topography-driven flow. The $\beta$ coefficients in equation (1) are very sensitive in the fitting procedure, which provides a very limited uncertainty related to the magnitude attributed to both terms of the model. The first term integrates local water transfers, closely related to the topographic features, and the importance of these transfers is well established by the coefficient $\beta_{1}$. The second term of equation (1) relates to more regional water transfers within the whole aquifer. An important added value of this study pertains to the use of this two-compartment model in relation with local and regional water transfers but also to the possibility to calculate the associated volumes using the simple exponential of equation (1)'s second term. The main conclusion of this analysis is that the volume attributed to the "regional" or "slow" compartment is significantly less sensitive to the recharge variations, compared with the characteristic times and $\beta$ coefficient sensitivities (Figure 11). The shape of circulation cells can, however, change significantly (Figure 12). The methodology used here constitutes an efficient tool to segregate and quantity local and regional processes from a quantitative point of view.

\subsection{Influence of Topography}

[29] Topography is the critical parameter that controls the flow partitioning between aquifers and rivers [Toth, 1963] as well as the transit lengths and times in groundwater. McGlynn et al. [2003] found a positive correlation between the mean residence time and the median subcatchment area. McGuire et al. [2005] highlighted the importance of the flow path length and flow path gradient on residence times. The results of our study are qualitatively consistent with these conclusions; but we bring new quantitative elements on the impact of recharge rates tested over a large interval. The distribution of groundwater discharge outlets is clearly controlled by topography, which in turn controls the partitioning between deep and shallow groundwater compartments.

[30] The fast local shallow compartment always connects hillslopes to adjacent rivers. Its extent is thus controlled by the average hillslope size, which is known to be a characteristic geomorphic feature that can be observed on the classical slope-area relationship of geomorphologists [Ijjasz-Vasquez and Bras, 1995; Montgomery and Dietrich, 1992]. For Brittany, the average hillslope area is about $0.5 \mathrm{~km}^{2}$, entailing a characteristic length scale of about $0.5-1 \mathrm{~km}$ (Figure 3). The hillslope length is similar to the average flow pathway length of the shallow compartment (Figure 10).

[31] The shallow compartment exists no more in regions where channels are dry; in this case, the recharge mainly feeds the deep aquifer. This observation explains two results of our study: (1) The fact that the characteristics (distance and transit time) of the shallow compartment remain almost unchanged when changing recharge rate. (2) The fact that the percentage of recharge feeding the deep compartment increases when decreasing recharge (and consequently river density).

[32] This result concerning recharge was also observed by Gleeson and Manning [2008] for generic and smaller mountainous basins. For the regional compartment, we
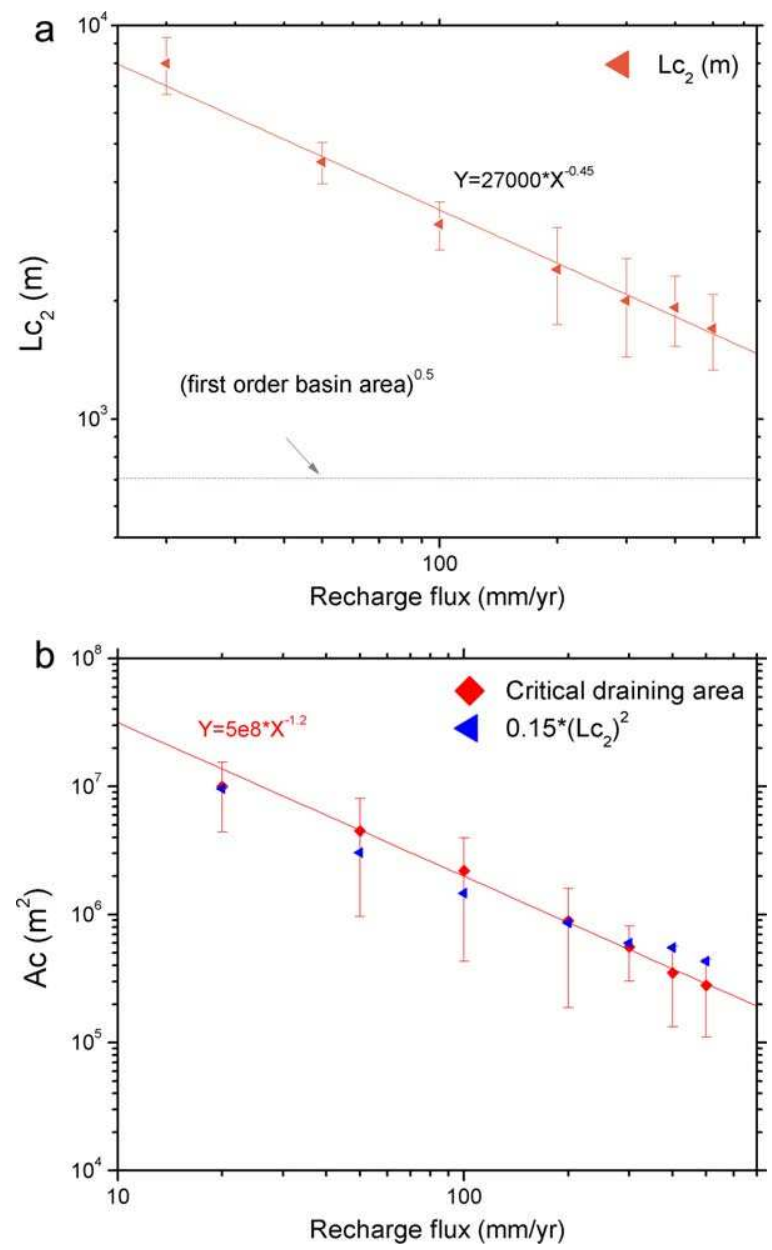

Figure 13. Evolution of the (a) characteristic length $\left(\mathrm{Lc}_{2}\right)$ and (b) critical drainage area $\left(A_{\mathrm{c}}\right)$ as a function of the total recharge flux $(R)$.

observe that the average transit times and pathway lengths increase when recharge decreases. This is likely due to both the decrease of hydraulic gradient between recharge and discharge zones (Figure 5), and to the decrease of river density that entails an increase of the distance between recharge inlets and discharge outlets as shown in Figures 7 and 10. Figure 13a shows this decrease of the characteristic length $\mathrm{Lc}_{2}$ with increasing recharge; it also emphasizes that the hillslope size is likely a lower limit of $\mathrm{Lc}_{2}$ at large recharge.

[33] In order to understand the link between the flow pathway lengths and topography characteristics, we calculate for each simulation the critical drainage area, $A_{\mathrm{c}}$, below which the piezometric surface differs from topography. To do this, we calculate the slope-drainage area of each piezometric surface and compare it to its equivalent for topography (Figure 3 ). Both curves are identical at large areas but differs below $A_{\mathrm{c}}$. $A_{\mathrm{c}}$ quantifies the drainage area of actual channel heads and thus measures the drainage density. Figure $13 \mathrm{~b}$ shows the evolution of $A_{\mathrm{c}}$ with recharge. Logically, it decreases with increasing recharge and varies in the same way as $0.15 \times \mathrm{Lc}_{2}{ }^{2}$. This relation demonstrates that the flow pathway length is on average a simple function of the drainage density. 


\subsection{Modeling Issues and Possible Improvements}

[34] In this study, the simulations have been performed using a real topography of South Brittany, characterized by a first-order catchment area of approximately $0.5 \mathrm{~km}^{2}$. The resolution of the finite difference grid has been chosen according to this topography. The use of $200 \times 200 \mathrm{~m}$ cells implies that each first-order catchment is covered by 12 cells on an average. This is actually necessary to ensure that these basic catchments are represented by more than one cell, so that flow can be simulated at this scale.

[35] The size of the modeled domain was chosen to include three main watersheds. This was intended to simulate the evolution of a large range of hydrogeological basins, according to recharge conditions (Figures 6 and 7). According to previous works and the results of this study, the total area of the modeled domain should not change transit times as long as each watershed is hydrologically independent of the others. In real systems, we know that there exist deep fluxes in between large watersheds that should be considered for calculating transit times. They are likely of very small proportion of the total for high recharge rates but may be nonnegligible for low recharge rates when the water table is deeper. In this study, the modeled domain includes major rivers and main topographic crests between northern and southern Brittany coasts. We therefore assume that the boundaries of the model correspond to the limits of permanent hydrogeological basins. Considering a larger domain should not influence the distributions [Marani et al., 2001].

[36] Finally, the bottom of the model has been arbitrarily fixed to $1000 \mathrm{~m}$ below the sea level. Modifying the elevation of this limit will clearly have an influence on the transit times (see the second term of equation (1)). This influence remains to be studied but does not change the conclusions regarding the methodology followed in this study.

\section{Conclusions and Perspectives}

[37] A regional-scale finite difference flow model was implemented to study the partitioning of recharge between different groundwater compartments. The model covers an area of $1400 \mathrm{~km}^{2}$, a depth of $1 \mathrm{~km}$, and the topography is characteristic of a Brittany watershed outflowing in the Atlantic Ocean. The fact of using a genuine topography is intended to capture the complex wavelength structure of this critical parameter for the groundwater-surface exchanges. The modeling cannot be considered per se as a regional study, but we wish that the topographic pattern has some general properties encountered in similar regions. "Drain" boundary conditions have been used on the whole modeled surface so that the river network is not prescribed but dependent on simulated groundwater conditions. Different recharge conditions, from 20 to $500 \mathrm{~mm} / \mathrm{yr}$, have been applied as input for the model, and transit time distributions have been calculated by use of particle tracking.

[38] The transit-time and travel-distance distributions exhibit an exponential trend for the longer times/distances. This is consistent with a slow, large and deep reservoir. At shortest times/distances, the distribution significantly departs from the previous exponential trend. There is not a single characteristic time or distance scale as for the previous compartment, but a range of values that are much smaller. The analysis of particle paths shows that this is a shallow compartment that links hillslopes to the neighboring river. The dichotomy between a shallow and a deep reservoir is valid for all recharge fluxes that have been explored by the simulations. However, the time and length scales are different for both compartments and influenced by the total recharge rate. This emphasizes the critical role of the river network, which is both the by-product and the boundary condition of groundwater fluxes. A denser network will favor shorter travel distances for both shallow and deep compartments.

[39] The results underline the importance of an adequate representation of these discharge zones in numerical models. This is particularly crucial in systems where the temporal variability of the recharge rates and the sensitivity of the discharge zones repartition are expected to be high. The use of drain or seepage face boundary conditions over the whole domain constitutes a useful and flexible solution.

[40] The double-compartment model allows us to easily quantify the partitioning of recharge between both compartments and the volumes associated to the related compartments. The evolution of $\beta_{2}$ coefficients shows that the proportion of the total recharge feeding the regional compartment increases as recharge decreases (proportionally to $\sim$ recharge ${ }^{-0.4}$ ). Absolute recharge rates to this compartment $\left(Q_{2}\right)$, however, decrease with total recharge (proportionally to $\sim$ recharge $\left.{ }^{+0.6}\right)$. Characteristic time $\left(\mathrm{Tc}_{2}\right)$ increases as recharge decreases (proportionally to $\sim$ recharge $^{-0.6}$ ). As the volume associated to regional water transfers is equal to the product of $Q_{2}$ and $\mathrm{Tc}_{2}$, it is shown that this volume is relatively less sensitive to total recharge and only decreases slightly when recharge increases.

[41] Finally, the numerical simulations allowed to visualize 3-D circulation cells, as those provided by Toth [1963] in 2-D. The occurrence of local and regional transfers is also observed, but the shape of circulation cells is modified with depth due to 3-D effects.

[42] In summary, the originality of this work is linked to the analysis of flow structure as a function of recharge, at the regional scale, including deep aquifer, in 3-D, and representing variable discharges zones using flexible river-aquifer boundary conditions. This work studies and quantifies "local" and regional processes using a double compartment model, and related volumes in the aquifer. The analysis can provide important information for example in the context of nonpoint source contamination and the fate of solute as a function of the time spent in the aquifer.

[43] Future work should be devoted to increase the complexity of the system. Introducing a heterogeneous geology, such as shallow more permeable units and deep bedrock should favor shallow groundwater flow. It would be interesting to study how the compartments model is applicable in this case and how the distributions and volumes presented in this paper are modified. Similarly, the flow structure according to recharge fluctuations is probably not the same, considering a relief characterized by deep canyons or small hills. Studying different topography features would bring new insights regarding their influence.

[44] Acknowledgments. This work has been developed in the framework of the project CLIMAWAT (Adapting to the Impacts of Climate Change on Groundwater Quantity and Quality), EU-RDF INTERREG IVA 
France (Channel)-England program. Thanks to H. Haitjema, T. Gleeson, and a third anonymous reviewer for their remarks and comments, which contributed to improve this paper.

\section{References}

Asano, Y., T. Uchida, and N. Ohte (2002), Residence times and flow paths of water in steep unchannelled catchments, Tanakami, Japan, J. Hydrol., 261(1-4), 173-192.

Cardenas, M. B. (2007), Potential contribution of topography-driven regional groundwater flow to fractal stream chemistry: Residence time distribution analysis of Toth flow, Geophys. Res. Lett., 34, doi: 10.1029/ 2006 GL029126.

Cornaton, F., and P. Perrochet (2006), Groundwater age, life expectancy and transit time distributions in advective-dispersive systems: 1. Generalized reservoir theory, Adv. Water Resour., 29, 1267-1291.

Craig, J. R. (2008), Analytical solutions for 2D topography-driven flow in stratified and syncline aquifers, Adv. Water Resour., 31(8), 1066-1073.

Dahl, M., B. Nilsson, J. H. Langhoff, and J. C. Refsgaard (2007), Review of classification systems and new multiple-scale typology of groundwatersurface water interaction, J. Hydrol., 344, 1-16.

Fiori, A., and D. Russo (2008), Travel time distribution in a hillslope: Insight from numerical simulations, Water Resour. Res., 44, dio: 10.1029/2008WR007135.

Fiori, A., D. Russo, and M. Di Lazzaro (2009), Stochastic analysis of transport in hillslopes: Travel time distribution and source zone dispersion, Water Resour. Res., 45, doi: 10.1029/2008WR007668.

Fleckenstein, J. H., R. G. Niswonger, and G. E. Fogg (2006), River-aquifer interactions, geologic heterogeneity, and low flow management, Ground Water, 44(6), 837-852.

Freeze, R. A., and P. A. Witherspoon (1967), Theoretical analysis of regional groundwater flow: 2. Effect of water-table configuration and subsurface permeability variation, Water Resour. Res., 3(2), 623-634.

Frei, S., J. H. Fleckenstein, S. J. Kollet, and R. M. Maxwell (2009), Patterns and dynamics of river-aquifer exchange with variably-saturated flow using a fully-coupled model, J. Hydrol., 375(3-4), 383-393.

Gelhar, L. W., and J. L. Wilson (1974), Ground-water quality modeling, Ground Water, 12(6), 399-408.

Gleeson, T., and A. H. Manning (2008), Regional groundwater flow in mountainous terrain: Three-dimensional simulations of topographic and hydrogeologic controls, Water Resour. Res., 44, doi: 10.1029/ 2008WR006848.

Goderniaux, P., S. Brouyère, S. Blenkinsop, A. Burton, H. J. Fowler, P. Orban, and A. Dassargues (2011), Modeling climate change impacts on groundwater resources using transient stochastic climatic scenarios, Water Resour. Res., 47, doi : 10.1029/2010WR010082.

Haitjema, H. M. (1995), On the residence time distribution in idealized groundwatersheds, J. Hydrol., 172(1-4), 127-146.

Haitjema, H. M., and S. Mitchell-Bruker (2005), Are water tables a subdued replica of the topography?, Ground Water, 43(6), 781-786.

Harbaugh, A. W., E. R. Banta, M. C. Hill, and M. G. McDonald (2000), MODFLOW-2000: The U.S. Geological Survey modular ground-water model. User guide to modularization concepts and the ground-water flow process, Open-File Rep. 00-92, 121 pp, U.S. Geol. Surv., Reston, Va.

Ijjasz-Vasquez, E. J., and R. L. Bras (1995), Scaling regimes of local slope versus contributing area in digital elevation models, Geomorphology, 12(4), 299-311.

Jiang, X. W., X. S. Wang, L. Wan, and S. M. Ge (2011), An analytical study on stagnation points in nested flow systems in basins with depth-decaying hydraulic conductivity, Water Resour. Res., 47, doi: 10.1029/ 2010WR009346.

Jones, J. P., E. A. Sudicky, and R. G. McLaren (2008), Application of a fully-integrated surface-subsurface flow model at the watershed-scale: A case study, Water Resour. Res., 44, doi: 10.1029/2006WR005603.

Kirchner, J. W., X. Feng, and C. Neal (2000), Frail chemistry and its implications for contaminant transport in catchments, Nature, 403(6769), 524-527.

Kirchner, J. W., X. Feng, and C. Neal (2001), Catchment-scale advection and dispersion as a mechanism for fractal scaling in stream tracer concentrations, J. Hydrol., 254, 82-101.
Leray, S., J. R. De Dreuzy, O. Bour, L. Aquilina, and T. Labasque (2012), Contribution of age data to the characterization of complex aquifers, J. Hydrol., 464-465, 54-68.

Lerner, D. N., and K. T. Papatolios (1993), A simple analytical approach for predicting nitrate concentrations in pumped ground water, Ground Water, 31(3), 370-375.

Liang, X., D. Quan, M. Jin, Y. Liu, and R. Zhang (2012), Numerical simulation of groundwater flow patterns using flux as upper boundary, Hydrol. Process, doi: 10.1002/hyp.9477.

Luther, K. H., and H. M. Haitjema (1998), Numerical experiments on the residence time distributions of heterogeneous groundwatersheds, J. Hydrol., 207(1-2), 1-17.

Maloszewski, P., and A. Zuber (1982), Determining the turnover time of groundwater systems with the aid of environmental tracers: 1. Models and their applicability, J. Hydrol., 57, 207-231.

Maloszewski, P., and A. Zuber (1996), Lumped parameter models for the interpretation of environmental tracer data, in Manual on Mathematical Models in Isotope Hydrology, Rep. IAEA-TECDOC 910, pp. 9-58, IAEA, Vienna.

Maloszewski, P., W. Rauert, W. Stichler, and A. Herrmann (1983), Application of flow models in an alpine catchment area using tritium and deuterium data, J. Hydrol., 66(1-4), 319-330.

Marani, M., E. Eltahir, and A. Rinaldo (2001), Geomorphic controls on regional base flow, Water Resour. Res., 37(10), 2619-2630.

McGlynn, B., J. McDonnell, M. Stewart, and J. Seibert (2003), On the relationships between catchment scale and streamwater mean residence time, Hydrol. Process., 17(1), 175-181.

McGuire, K. J., and J. J. McDonnell (2006), A review and evaluation of catchment transit time modeling, J. Hydrol., 330(3-4), 543-563.

McGuire, K. J., J. J. McDonnell, M. Weiler, C. Kendall, B. L. McGlynn, J. M. Welker, and J. Seibert (2005), The role of topography on catchmentscale water residence time, Water Resour. Res., 41, doi: 10.1029/ 2004WR003657.

Montgomery, D. R., and W. E. Dietrich (1989), Source areas, drainage density, and channel initiation, Water Resour. Res., 25(8), 1907-1918.

Montgomery, D. R., and W. E. Dietrich (1992), Channel initiation and the problem of landscape scale, Science, 255(5046), 826-830.

Montgomery, D. R., and E. Foufoulageorgiou (1993), Channel network source representation using digital elevation models, Water Resour. Res., 29(12), 3925-3934.

Pollock, D. W. (1994), User's guide for MODPATH/MODPATH-PLOT, Version 3: A particle tracking post-processing package for MODFLOW, the U.S. Geological Survey finite-difference ground-water flow model, U.S. Geol. Surv. Open-File Report, USA, pp. 94- 464.

Reilly, T. E. (2001), System and Boundary Conceptualization in GroundWater Flow Simulation, U.S. Geol. Surv, USA.

Rodgers, P., C. Soulsby, S. Waldron, and D. Tetzlaff (2005), Using stable isotope tracers to assess hydrological flow paths, residence times and landscape influences in a nested mesoscale catchment, Hydrol. Earth Syst. Sci., 9(3), 139-155.

Sanford, W. (2002), Recharge and groundwater models: An overview, Hydrogeol. J., 10, 110-120.

Scibek, J., D. M. Allen, A. J. Cannon, and P. H. Whitfield (2007), Groundwater-surface water interaction under scenarios of climate change using a high-resolution transient groundwater model, J. Hydrol., 333(2-4), $165-181$.

Sophocleous, M. (2002), Interactions between groundwater and surface water: The state of the science, Hydrogeol. J., 10, 52-67.

Toth, J. (1963), A theoretical analysis of groundwater flow in small drainage basins, J. Geophys. Res., 68(16), 4795-4812.

Uhlenbrook, S., M. Frey, C. Leibundgut, and P. Maloszewski (2002), Hydrograph separations in a mesoscale mountainous basin at event and seasonal timescales, Water Resour. Res., 38(6), 311-314.

Weiler, M., B. L. McGlynn, K. J. McGuire, and J. J. McDonnell (2003), How does rainfall become runoff? A combined tracer and runoff transfer function approach, Water Resour. Res., 39(11), SWC41-SWC413.

Winter, T. C. (1978), Numerical-simulation of steady-state 3-dimensional groundwater flow near lakes, Water Resour. Res., 14(2), 245-254.

Zijl, W. (1999), Scale aspects of groundwater flow and transport systems, Hydrogeol. J., 7(1), 139-150. 